http://dx.doi.org/10.12775/szhf.2014.053

\title{
Paweł Wójs, Rozum w filozofii egzystencji, Universitas, Kraków 2013, ss. 241
}

W ostatnim czasie nakładem krakowskiego wydawnictwa Universitas ukazała się książka pracownika Uniwersytetu Pedagogicznego w Krakowie Pawła Wójsa pt. Rozum w filozofii egzystencji. Tematem rozprawy, jak zaznacza jej autor, jest przedstawienie „sposobów ujmowania rozumu w filozofii egzystencji”, celem zaś „wykazanie, że krytyka rozumu, a niekiedy walka toczona $\mathrm{z}$ nim na gruncie filozofii egzystencji, może być pojmowana nie tyle jako odrzucenie rozumu czy jego negacja, ile raczej jako określanie właściwego mu pojmowania i pozycji w filozofii”" . Wójs stwierdza, iż błędem było przeświadczenie, że pojęcie rozumu w filozofii egzystencji zeszło na dalszy plan. W toku swojego wywodu stara się udowodnić, że zagadnienie rozumu na polu filozofii egzystencji nabrało nowych znaczeń i otworzyło mnóstwo ścieżek interpretacyjnych.

Wójs rozpoczyna swoją rozprawę od omówienia najbardziej podstawowych kwestii: (1) w zarysie historycznym pokazuje, jak pojęcie rozumu zmieniało się $\mathrm{w}$ tradycji i kulturze. $\mathrm{W}$ tym celu pokrótce omawia koncepcje filozoficzne najwybitniejszych filozofów, którzy w swoich dziełach zajmowali się zagadnieniem rozumu (Arystoteles, Augustyn, Hegel, Kant); (2) wyjaśnia, czym jest filozofia egzystencji: wskazuje jej cechy, prekursorów, głównych przedstawicieli, czyli Jaspersa i Heideggera ${ }^{2}$, a także bardzo skrótowo przedstawia podstawowe założenia ich filozofii.

\footnotetext{
${ }^{1}$ P. Wójs, Rozum w filozofii egzystencji, Universitas, Kraków 2013, s. 7.

${ }^{2}$ Wójs za czołowego przedstawiciela filozofii egzystencji nie uznaje Jean Paula Sartre’a. Pisze, powołując się na opinię Tymona Terleckiego (zob. P. Wójs, Rozum w filozofii egzystencji, dz. cyt., s. 29), że to Marcel, a nie Sartre był czołowym i pierwszym przedstawicielem filozofii egzystencji na gruncie francuskim. Odmienne stanowisko w tej kwestii reprezentuje na przykład
} 
Po tak zarysowanym wprowadzeniu do rozważanych kwestii autor przechodzi do głównej części swojej rozprawy, mianowicie spośród myślicieli, którzy zajmowali się problematyką egzystencjalną, wybiera trzech (Camusa, Szestowa oraz Jaspersa) i omawiając ich koncepcje filozoficzne, próbuje udowodnić swoją tezę o zakorzenieniu się pojęcia rozumu na polu filozofii egzystencji. Wybór wyżej wymienionych przedstawicieli może dziwić, Szestow bowiem, który zajmował się oczywiście problematyką egzystencjalną, nie jest jednak zaliczany (podobnie jak Camus) do najważniejszych przedstawicieli tego nurtu filozoficznego. Wójs zdaje sobie $\mathrm{z}$ tego sprawę i jasno uzasadnia czytelnikowi swój wybór. Uważa, że wybrani przez niego filozofowie, mimo że czołowymi przedstawicielami nurtu egzystencjalnego nie są, to (1) i tak wpisują się w założenia nurtu filozofii egzystencji, (2) zajmują się zagadnieniem rozumu, prezentując odmienne jego koncepcje. Dokonując wyboru takich, a nie innych myślicieli, autor może dzięki temu ująć i opisać trzy różne sposoby przedstawienie pojęcia rozumu w filozofii egzystencji, a w konsekwencji uzasadnić swoją podstawową tezę o tym, że na gruncie filozofii egzystencji pojęcie rozumu zostało rzucone na zupełnie nowe ścieżki interpretacyjne.

Stosunek Alberta Camusa do pojęcia rozumu Wójs rozpatruje w kontekście dwóch kluczowych dla francuskiego myśliciela pojęć: absurdu i buntu, a także w relacji do mniej znanego aspektu jego filozofii, a mianowicie „myśli południa". Wywód rozpoczyna od opisania pojęcia absurdu. W tym celu sięga przede wszystkim do mitu Syzyfa. Swoje rozważania rozszerza, wprowadzając wątki filozofii Sartre’a, Ciorana i Platona. Nawiązuje do zagadnienia sensu, pisze o relacji absurd-sens, oraz o rozróżnieniu absurd-absurdalność.

Camus odrzuca sposób pojmowania rozumu jako czegoś uniwersalnego, za pomocą czego człowiek jest $\mathrm{w}$ stanie dojść do poznania siebie, innych ludzi i otaczającego go świata. Daremne są próby racjonalizowania świata, zważywszy na to, że francuski myśliciel nieustannie podkreśla absurdalność ludzkiego istnienia, natomiast świat opisuje jako coś milczącego i irracjonalnego. Z drugiej jednak strony, filozof zaznacza, że nie można całkowicie zanegować pojęcia rozumu. Francuski myśliciel uznaje rozum za pewnego rodzaju narzędzie do poznawania świata, za pomocą którego człowiek uświadamia

Mirosław Żelazny, który w swojej monografii Psychologia i filozofia egzystencjalna uznaje Sartre’a, obok Jaspersa i Heideggera, za czołowego przedstawiciela filozofii egzystencji. Wójs, powołując się na różne źródła ( $w$ tym m.in. dzieła Bierdiajewa, Camusa i Wahla), przedstawia problem związany z określeniem, którzy myśliciele są, a którzy nie są reprezentantami filozofii egzystencji. Zob. P. Wójs, Rozum... dz. cyt., s. 34-35. 
sobie własne ograniczenia poznawcze. Rozum nie jest w stanie poznać czegoś obcego, ale to właśnie dzięki własnym staraniom do objęcia świata w pełni może uświadomić sobie własne granice poznawcze. Zagadnieniem relacji pomiędzy ograniczonymi zdolnościami poznawczymi człowieka a światem Camus zajmuje się pod koniec swojej twórczości w tzw. „myśli południa”. "Zasadę harmonii między śmiertelnym człowiekiem o ograniczonych możliwościach poznawczych a światem Camus określił mianem »myśli południa «, jako alternatywy dla ciemnej, pesymistycznej myśli północy"' Zgodnie z koncepcją „myśli południa” należy posługiwać się rozumem w granicach mu przeznaczonych. Rozum ludzki nie może pretendować do poznania na przykład rzeczy samych w sobie. Człowiek Camusowski nie musi przyjmować istnienia transcendencji, a jego rozum ma pozwalać mu na życie we własnej skali i własnym porządku poznawczym. „Camus, pisząc o rozumie, miał na myśli rozum arystotelesowski - znajdujący miarę" ${ }^{\prime 4}$ podsumowuje swoje rozważania Wójs.

Zdecydowanie bardziej krytyczne stanowisko w stosunku do pojęcia rozumu, reprezentuje Szestow: „Myśl Szestowa jest skrajnie antyracjonalistyczna, stara się obalić całą tradycję filozofii Zachodu opierającą się na rozumie" ${ }^{5}$ wyjaśnia Wójs na początku rozdziału dotyczącego rosyjskiego myśliciela. Zagadnienie rozumu u Szestowa Wójs opisuje w kontekście ważnego dla rosyjskiego myśliciela pojęcia tragedii. Czytamy: „nie można jej [tragedii M. Ch.] uniknąć [...]. Tragedię należy przyjąć, nie da się jej zapobiec, nie można jej uniknąć, niemożliwe okazuje się nawet opóźnienie jej nadejścia. Tragedia rozgrywa się bez aktywnego, świadomego udziału człowieka, dopada go. Znika więc wszelka nadzieja, zwłaszcza na powrót do dawnego życia"6. Doświadczenie tragedii polega na poczuciu bycia w sytuacji bez wyjścia. W obliczu tragedii człowiek jest samotny, pozostaje sam ze swoim cierpieniem. Wrzucenie na obcy teren jest równoznaczne $\mathrm{z}$ utratą zdolności poznawania. Zatem w obliczu tragiczności na nic nie zda się rozum.

Szestow wyróżnia dwa sposoby myślenia: pierwszy helleński, reprezentowany przez miasto Ateny, jest myśleniem racjonalistycznym. Wedle filozofii racjonalistycznej rozum ludzki kieruje się niezmiennymi i uniwersalnymi zasadami. Jednak wieczne prawa rozumu ograniczają wolność oraz „pełnią

\footnotetext{
${ }^{3}$ Tamże, s. 88.

${ }^{4}$ Tamże, s. 218.

5 Tamże, s. 94.

${ }^{6}$ Tamże, s. 98.
} 
funkcję usypiania ludzkiej świadomości wizją deterministycznego przebiegu zdarzeń i mamią rzekomym istnieniem prawd odwiecznych oraz praw obowiązujących powszechnie" ". Szestow uznaje rozum tylko za władzę służącą na przykład do rozwiązywania problemów matematycznych. Myśliciel apeluje, aby odsunąć się od porządku racjonalistycznego w stronę myślenia biblijnego, reprezentowanego przez Jerozolimę. Jest to myślenie religijne oparte na wierze $\mathrm{w}$ to, że wola boska nie podlega niczemu. Życie człowieka nie ma opierać się na wiecznych rozumowych prawdach, lecz na niewiedzy, ufności i bezgranicznej wierze w Boga.

Ostatnim omawianym myślicielem, który w swojej filozofii zajmował się zagadnieniem rozumu, jest Karl Jaspers, dla którego rozum odgrywa rolę przewodnika na drodze poznania. Wójs skupia się przede wszystkim na opisie Jaspersowskich relacji między nauką, filozofią i religią. Autor słusznie zwraca uwagę na to, że filozofia Jaspersa wyrasta przede wszystkim ze związku z myślą Kanta, wyznaczoną przez trzy podstawowe pytania filozoficzne: co mogę wiedzieć?, co powinienem zrobić?, czego mogę się spodziewać?

Pierwszy tom Philosophie Jaspersa zawiera próbę określenia istoty pierwszego z Kantowskich pytań: „co możemy wiedzieć?”. Wedle niemieckiego filozofa temu pytaniu odpowiada fenomen realności. Na pytanie: „,o powinniśmy robić?” Jaspers próbuje odpowiedzieć w drugiej części dzieła, zatytułowanej Rozjaśnianie egzystencji. Na to pytanie filozof odpowiada: rozjaśniaj egzystencję. Trzecia część Philosophie, zatytułowana Metafizyka, odnosi się do kwestii: „czego możemy się spodziewać?”. Z tym pytaniem wiąże się ważne pojęcie zwane szyfrem transcendencji, które jest próbą wypowiedzenia swej tęsknoty za czymś, co jest nam potrzebne, lecz nieuchwytne. Ta sfera opiera się na wierze $\mathrm{w}$ istnienie tego czegoś.

Wójs zauważa, że w koncepcji Jaspersa nauce ma odpowiadać wiedza naukowa, objawieniu - wiara religijna, natomiast rozumowi (filozofii) wiara filozoficzna. Powyższe trzy człony nie negują się nawzajem. Jaspers opowiada się za współdziałaniem rozumu i intelektu, odrzuca podkreślany przez Szestowa ścisły podział na to, co racjonalne i to, co irracjonalne. W zamian za to proponuje „trójpodział na naukę, filozofię i teologię, czyli na autonomiczną

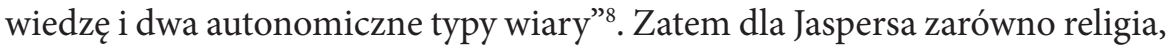
filozofia oraz poznanie naukowe znajdują się w jednej przestrzeni, nie znosząc się nawzajem.

7 Tamże, s. 128

8 Tamże, s. 174. 
Powyższe trzy koncepcje Wójs opisuje niezwykle starannie i szczegółowo. Uważa on, że nie da się ująć w jednym nurcie różnorodności wypracowanych przez omówionych filozofów opisów pojęcia rozumu. W dalszym toku swojego wywodu stwierdza jednak, co jest zaskakujące, że w rozważania trzech omówionych filozofów można znaleźć wspólny punkt. W zakończeniu swojej rozprawy wprowadza termin, który „jednoczy różnorodność", czyli ujmuje w jedno wszystkie odmienne koncepcje rozumu w filozofii egzystencji. Autor proponuje wprowadzić ukute przez holenderskiego filozofa Williama Luijpena pojęcie „rozumu rozszerzonego” jako kategorii „która może rozwiązać tak różnorodną myśl, jak ta dotycząca problemu rozumu w filozofii egzystencji” ${ }^{10}$. Wprowadzone przez niego pojęcie jest odpowiedzią na wielość ścieżek interpetacyjnych kategorii rozumu. Owym rozumem rozszerzonym miałby być rozum, którym zajmowali się filozofowie zaliczani do nurtu filozofii egzystencji i których pomysłów na opis owego pojęcia nie da się ująć w jedną całość.

Książka ma klarowny podział. Mimo trudnych zagadnień jest napisana bardzo zrozumiałym językiem. Do każdego rozdziału autor proponuje krótki wstęp historyczny. Każdy z przedstawionych myślicieli jest omówiony w szerokim kontekście filozoficzno-historycznym. Wrażenie robi imponująca bibliografia. Książka jest godna polecenia wszystkim czytelnikom interesującym się filozofią egzystencji.

9 Tamże, s. 220.

${ }^{10}$ Tamże, s. 222. 